\title{
Global Public Goods and Democracy in International Legal Scholarship
}

\author{
Samuel Cogolati, ${ }^{*}$ Linda Hamid $^{* *}$ and Nils Vanstappen ${ }^{* * *}$
}

\begin{abstract}
Over the last decade, global public goods (GPGs) have been at the centre of the policy discourse of prominent international organisations, States, and non-government organisations (NGOs) alike. The concept emerged in 1999, in a seminal book sponsored by the United Nations Development Programme (UNDP), and finds its origins in economic theory. The economic literature defines public goods as non-rival, since anyone can benefit from them without diminishing the quantity available to other consumers, and non-excludable, as no one can realistically be excluded from their consumption. Nowadays, an increasing number of public goods transcend national boundaries. For instance: climate change mitigation, the eradication of infectious diseases, the fight against corruption, or the protection of the ozone layer are all seen as GPGs. But despite its topicality, the concept has attracted little attention from legal scholars around the globe. Not only this, but among the few authors that actually engage with the topic, the majority focus on issues related to the provision of GPGs, while the question of what goods should be publicly provided in the first place, as well as the decision-making process underlying such a determination, has been left largely unexplored. It is with respect to this specific issue that we wish to contribute to the debate. In our view, the definition of GPGs is a matter of policy choice, as it goes beyond economic, value-free considerations. Therefore, it cannot lie beyond the control of democratic structures. GPGs cannot be defined in a democratic and legal vacuum-a legitimate and inclusive decision-making process is required. In this article, we endeavour to explain how international legal scholarship, in particular the global administrative law and global constitutionalism projects, can contribute to integrating democratic standards in the process of defining GPGs.
\end{abstract}

\section{Keywords}

Global Public Goods, Democracy, Participation, Global Administrative Law and Global Constitutionalism

* Doctoral Researcher, 'Global Governance and Democratic Government' at the Leuven Centre for Global Governance Studies, Katholieke Universiteit Leuven (Belgium) and PhD Fellow at the Research Foundation - Flanders (FWO) (Belgium).

** Doctoral Researcher, 'Global Governance and Democratic Government' at the Leuven Centre for Global Governance Studies, Katholieke Universiteit Leuven (Belgium).

*** Doctoral Researcher, 'Global Governance and Democratic Government' at the Leuven Centre for Global Governance Studies, Katholieke Universiteit Leuven (Belgium).

The authors would like to thank Dr. Axel Marx, Dr. Martin Deleixhe and the anonymous reviewers of the CJICL for their helpful comments. Any errors or omissions remain, of course, ours. 


\section{Introduction}

Over the last decade, global public goods (GPGs) have been at the centre of the policy discourse of prominent international organisations, States, and non-government organisations (NGOs) alike. The concept emerged in 1999 in a seminal book sponsored by the United Nations Development Programme (UNDP), and finds its origins in economic theory. ${ }^{1}$ Economic literature defines public goods as non-rival, since anyone can benefit from them without diminishing the quantity available to other consumers, and non-excludable, as no one can realistically be excluded from their consumption. ${ }^{2}$ Nowadays, an increasing number of public goods transcend national boundaries. For instance: climate change mitigation, the eradication of infectious diseases, the fight against corruption, or the protection of the ozone layer are all seen as GPGs. Despite its topicality, however, the concept has attracted little attention from legal scholars around the globe. Not only this, but among the few authors that actually engage with the topic, the majority focus on issues related to the provision of GPGs, while the question of what goods should be publicly provided in the first place, as well as the decision-making process underlying such a determination, has been left largely unexplored. It is with respect to this specific issue that we wish to contribute to the debate. In our view, the definition of GPGs is a matter of policy choice, as it goes beyond economic, value-free considerations. Therefore, it cannot lie beyond the control of democratic structures.

This article supports the broad thesis that GPGs cannot be defined in a democratic and legal vacuum, and that, as such, a legitimate process of decisionmaking is required. Yet, attempting to provide a fully-fledged democratic procedure to underlie the definition of GPGs within the constraints of the present article would be overly ambitious. Therefore, the scope of our study is methodologically limited in two ways. First, notwithstanding the importance of other democratic standards, such as accountability or transparency, the article operates on a narrower normative basis and focuses only on participation as a requisite standard in the definition of GPGs. Indeed, the UNDP has pinpointed the existence of a 'participation gap' as one of the central limitations of the current global governance architecture. In Cooperation in the 21st Century (OUP 1999).

2 See Paul Samuelson, 'The Pure Theory of Public Expenditure' (1954) 36(4) Rev Econ Stat 387; Tyler Cowen, 'Public Goods' in David R Henderson (ed), The Concise Encyclopedia of Economics (2008) (Liberty Fund 2008). 
this regard, enhanced representation and involvement of all affected stakeholders is seen as a basic precondition for a legitimate decision-making process on GPGs. Secondly, in an attempt to offer pathways in bridging this so-called participation gap, the article mostly focuses on the doctrinal contributions of two modern fields of international law-global administrative law and global constitutionalism. Accordingly, our analysis is mainly centred on academic commentary and, to a lesser extent, on primary sources of international law, as it is exactly this academic commentary which we attempt to redirect.

In view of the above, this contribution is structured as follows: we start by giving a short account of the emergence of the concept in both economic theory and the global policy discourse (section 2); thereafter, we discuss the normative undertone underlying the rhetoric of GPGs and the policy choices that inevitably surround the definition of GPGs (section 3); finally, we turn to the burgeoning international legal scholarship on GPGs (section 4); and we endeavour to explain how international legal scholarship, in particular the fields of global administrative law and global constitutionalism, can contribute to integrating participation as a democratic standard in the process of defining GPGs (section 5).

\section{The emergence of the global public goods discourse}

\subsection{Public goods theory}

The GPGs project is, in essence, grounded in the neoclassical economic theory of (national) public goods. Therefore, its roots lie outside the realm of international legal doctrine. Some background on the concept is thus warranted here. ${ }^{3}$ As opposed to a private good, such as a pie or a car, a public good refers to goods that are non-rival and non-excludable. ${ }^{4}$ A lighthouse, for example, is such a good, as any sailor can benefit from the light without diminishing its availability to others (non-rivalry), and no one can be prevented from using its light as a navigational Katell Le Goulven and Ronald U Mendoza (eds), Providing Global Public Goods: Managing Globalization (OUP 2003) 63.

4 Compare with 'club goods' that are non-rival but excludable (eg a toll road), and 'common pool resources' that are rival but non-excludable (eg high seas fisheries or the geostationary orbit). 
aid (non-excludability). ${ }^{5}$ Due to these characteristics, public goods are structurally affected by free-rider and collective-action problems and, as such, suffer from under-provision.

Public goods represent a case of market failures-that is, goods and services that cannot be left to the invisible hand of the free market. By virtue of the inherent free-rider problem in the provision of public goods, coercive authority is considered necessary in ensuring, at the very least, a minimal contribution by all. ${ }^{6}$ Therefore, at the national level, State intervention is seen as indispensable in the financing and provision of public goods. In this respect, in one of his landmark articles, Paul Samuelson argued that, since the State is responsible for the welfare of its citizens, it must naturally also provide public goods. ${ }^{7}$ Likewise, but from a different standpoint, Mancur Olson defined the state as 'first of all an organization that provides public goods for its members, the citizens.

The neoclassical theory of public goods has, of course, also been criticised. Samuelson assumes that the welfare State is best suited to provide and distribute public goods because it could 'somehow' infer its citizens' preferences, but fails to discuss exactly how (ie, through which processes) governments can legitimately define public goods. ' Indeed, as Elisabetta Marmolo has indicated, 'whether or not their provision is legitimately within the domain of public action cannot be determined on the basis of a narrow criterion of economic efficiency. ${ }^{10}$ To a

5 A lighthouse is indeed most often cited as the classical example of a public good. However, its qualification as such has been challenged on several occasions, most notably by Ronald Coase. This shows that barely any goods can be considered 'pure' public goods. See Ronald H Coase, 'The Lighthouse in Economics' (1974) 17(2) JL Econ 357.

6 See Mancur Olson, The Logic of Collective Action: Public Goods and the Theory of Groups (HUP 1965) 98: '[m] ost economists accept a theory which implies that the basic services of government can be provided (...) only through compulsion. This is the theory of "public goods"'; see also Ian Loader and Neil Walker, 'Policing as a Public Good: Reconstituting the connections between Policing and the State' (2001) 5(1) Theor Criminol 9-35.

7 Samuelson (n 2). Although many authors trace the origins of the public goods concept back to Samuelson, the basis for his work can probably be found in earlier German scholarship; see also Richard Sturn, "Public goods" before Samuelson: Interwar Finanzwissenschaft and Musgrave's Synthesis' (2010) 17(2) Europ J Hist Econ 279.

8 Olson (n 6) 15.

9 Erik A Andersen and Birgit Lindsnaes, 'Public Goods: Concepts and Definition' in Erik A Andersen and Birgit Lindsnaes (eds), Towards New Global Strategies: Public Goods and Human Rights (Martinus Nijhoff 2007) 32.

10 Elisabetta Marmolo, 'A Constitutional Theory of Public Goods' (1999) 38(1) J Econ Behav Organ 27. 
large extent, the critics claim, the provision of public goods depends on political preferences. In this regard, Desai has argued that:

Far from being a neutral technical process of summing up preferences and locating the optimal solution through a social welfare function, as in Samuelson's characterisation, the provision of public goods is a political process-one influenced by elections and mediated by political parties. ${ }^{11}$

In the end, deciding on the public provision of certain goods is a political process that must be democratic in order to be legitimate. With this in mind, it becomes clear that modern liberal states draw their legitimacy from a 'democratically controlled framework that defines what counts as a public good. ${ }^{12}$

\subsection{The globalisation of public goods}

The origins of the GPGs project can be situated with the UNDP Office of Development Studies, which, in an attempt to understand the conceptual and methodological challenges, as well as the public policy dimensions surrounding the phenomenon, ${ }^{13}$ published three books on the topic in $1999,{ }^{14} 2003,{ }^{15}$ and $2006 .{ }^{16}$ According to Inge Kaul and her co-authors, in addition to sharing the properties of non-rivalry and non-excludability exposed above, GPGs should produce benefits that are available worldwide and across social strata. ${ }^{17}$ In this regard, they define GPGs as 'outcomes (or intermediate products) that tend towards universality in the sense that they benefit all countries, population groups, and generations. ${ }^{18}$

This definition means that, in contrast to neoclassical economic theory, the concept of 'goods', as reconstructed by the UNDP, covers a very large spectrum

11 Desai (n 3) 69; see below text to n 59-62.

12 Nico Krisch, 'Global Administrative Law and the Constitutional Ambition' in Petra Dobner and Martin Loughlin, The Twilight of Constitutionalism (OUP 2010) 250.

13 See also Scott Barrett, Why Cooperate? The Incentive to Supply Global Public Goods (OUP 2007); Todd Sandler, Global Collective Action (CUP 2004).

14 Kaul, Grunberg and Stern (n 1).

15 Kaul, Conceição, Le Goulven and Mendoza (n 3).

16 Inge Kaul and Pedro Conceição (eds), The New Public Finance: Responding to Global Challenges (OUP 2006).

17 Inge Kaul, Isabelle Grunberg and Marc A Stern, 'Defining Global Public Goods' in Kaul, Grunberg and Stern (n 1) 16. ibid. 
of global issues: ${ }^{19}$ 'natural global commons', such as the ozone layer or climate stability; 'human-made global commons', like cultural heritage ${ }^{20}$ or knowledge; ${ }^{21}$ and 'global policy outcomes', such as climate change mitigation ${ }^{22}$ and distributive justice. ${ }^{23}$ Under this approach, it should be stressed that there cannot be any fixed list of GPGs and the term 'good' should be understood in the broadest possible sense-not solely as a tangible commodity or a normative standard. GPGs simply point to policy challenges that cannot be adequately resolved at the State level and which, therefore, require collective action at the global level. For instance, the concept has now come to comprise economic governance and trade integration, the eradication of communicable diseases, environment and climate change, food security, and, for some, even democracy. ${ }^{24}$

The under-provision of such GPGs can be explained by drawing a parallel between the international and national levels. ${ }^{25}$ States, who-like individuals at the national level-are considered to act as rational, self-interested actors, will not be prepared to contribute or take upon themselves the task of providing GPGs without being somehow coerced to do so. Consider, for instance, major polluter countries such as the United States, which has never ratified the Kyoto Protocol. States and other global actors have an incentive to free-ride on the efforts of others, and in the absence of agreed upon collective action, this will inevitably lead to global underinvestment and undersupply.

According to the first UNDP study, the under-provision of GPGs is caused by three central weaknesses of the current global governance system: (i) the 'jurisdictional gap' or, in other words, the absence of a State-like entity at the global level for supplying GPGs, or at least enforcing contribution by all; (ii) the 'participation gap', namely the exclusion of certain groups of countries, population

We use the same three classes of global public goods as detailed in Kaul, Grunberg and Stern, 'Global Public Goods: Concepts, Policies and Strategies' in Kaul, Grunberg and Stern (n 1) 453-55.

20 See Ismail Serageldin, 'Cultural Heritage As Public Good: Economic Analysis Applied to Historic Cities' in Kaul, Grunberg and Stern (n 1) 241.

21 See Joseph E Stiglitz, 'Knowledge As a Global Public Good' in Kaul, Grunberg and Stern (n 1) 309.

22 See Scott Barrett, 'Montreal versus Kyoto: International Cooperation and the Global Environment' in Kaul, Grunberg and Stern (n 1) 193.

23 See Ethan B Kapstein, 'Distributive Justice as an International Public Good: A Historical Perspective' in Kaul, Grunberg and Stern (n 1) 89.

24 See Peter J Burnell, 'International Democracy Promotion: A Role for Public Goods Theory?' (2008) 14(1) Contemp Pol 41.

See above text to $n$ 6-9. 
groups, including future generations, civil society and business from the decisionmaking process surrounding the provision of GPGs; and (iii) the incentive gap, which refers to the lack of perceived benefits for those participating in the production and financing of GPGs at the international level. ${ }^{26}$

Over the last two decades, this concept has gradually permeated the policy discourse of a large number of international organisations, particularly in the field of development. ${ }^{27}$ Building upon an idea that emerged during the 2002 International Conference on Financing for Development and the 2002 World Summit on Sustainable Development, Sweden ${ }^{28}$ and France ${ }^{29}$ signed an agreement to initiate an International Task Force on GPGs. The Task Force, which was co-chaired by Ernesto Zedillo, former President of Mexico, and Tidjane Thiam, former Ivorian Minister of Development, was intended to translate the theoretical concept of GPGs as developed by the UNDP into a more practical tool for policy-makers. The Task Force published its final report in 2006 with a series of recommendations on the financing and production of GPGs, in particular, poverty-reduction. ${ }^{30}$ Meanwhile, the United Nations General Assembly (UNGA), ${ }^{31}$ the United Nations Industrial Development Organization (UNIDO), ${ }^{32}$ the Food and Agriculture Organization $(\mathrm{FAO}){ }^{33}$ the World Bank (WB), ${ }^{34}$ the Organisation for Economic Coordination

Kaul, Grunberg and Stern (n 1) xxvi.

Maurizio Carbone, 'Supporting or Resisting Global Public Goods? The Policy Dimension of a Contested Concept' (2007) 13(2) Glob Gov 179.

See the study on development financing prepared for the Swedish Ministry for Foreign Affairs, Francisco Sagasti and Keith Bezanson, Financing and Providing Global Public Goods: Expectations and Prospects (Regeringskansliet 2001).

9 See the French position on global public goods, Directorate-General for Development and International Cooperation, Ministry of Foreign Affairs, and Treasury Directorate, Ministry of the Economy, Finance and Industry ‘Global Public Goods' (February 2002) <www.diplomatie. gouv.fr/en/IMG/pdf/ biens_publ_gb.pdf> accessed 1 April 2016.

International Task Force on Global Public Goods, 'Meeting Global Challenges: International Cooperation in the National Interest' (2006) <www.ycsg.yale.edu/assets/downloads/meeting global_challenges_global_public_goods.pdf > accessed 1 April 2016.

1 See UNGA 'Recommendations of the High-level Panel on Financing for Development' (26 June 2001) UN Doc A/55/1000.

32 See UNIDO, 'Public Goods for Economic Development' (2008) <www.unido.org/ fileadmin/ user_media/Publications/documents/Public goods for economic development_sale.pdf> accessed 1 April 2016.

3 See FAO, 'The State of Food and Agriculture' (2002) <www.fao.org/docrep/004/y6000e/ y6000e00.htm $>$ accessed 1 April 2016.

See Development Committee, 'Poverty Reduction and Global Public Goods: Issues for the World Bank in Supporting Global Collective Action' (2000) DC/2000-16, 2. 
and Development (OECD) ${ }^{35}$ the World Health Organization (WHO), ${ }^{36}$ and the European Union $(\mathrm{EU})^{37}$ have all branded the provision of GPGs as a new policy challenge. In fact, the concept has been embraced by so many actors, in so many different contexts, that one commentator has pointed out that 'the risk is to create a catch-all to which people can attach anything they want. ${ }^{38}$

\section{The issue of democracy in the definition of global public goods}

\subsection{Global public goods as a legitimising instrument}

As is clear from the developments depicted here, GPGs have gradually become a buzzword in the global policy discourse, evolving from a technical, economic concept to a powerful advocacy tool in favour of increased international cooperation and regulation in today's globalised world. ${ }^{39}$ Beyond the Washington consensus, ${ }^{40}$ the concept of GPGs is now frequently used to justify a greater role for international organisations and, in the field of development aid, it has been adopted to highlight the need for a renewed model of development aid, for instance, by raising global

See the study on financing global public goods prepared for the OECD Development Centre: Helmut Reisen, Marcelo Soto and Thomas Weithöner, 'Financing Global and Regional Public Goods through ODA: Analysis and Evidence from the OECD Creditor Reporting System' (2004) 232 Development Centre Working Papers 1, 11.

36 See WHO, 'Global Public Goods' (2016) < www.who.int/trade/glossary/story041/en/> accessed 1 April 2016.

37 See European Commission, 'EU Focus on Global Public Goods' (2002) <http://ec.europa.eu/ environment/archives/wssd/pdf/publicgoods.pdf > accessed 1 April 2016; Council Regulation (EC) 233/2014 of 11 March 2014 establishing a financing instrument for development cooperation for the period 2014-2020 [2014] OJ L 77/44; European Report on Development, 'Combining Finance and Policies to Implement a Transformative Post-2015 Development Agenda' (2015) <http://ecdpm.org/wp-content/uploads/2015-European-Report-onDevelopment-English.pdf $>$ accessed 1 April 2016; see also Mikaela Gavas, 'The EU and Global Public Goods: Challenges and Opportunities', DIIS Report 2013:05 <http://um.dk/en/ / media/UM/English-site/Documents/Danida/Partners/Research-Org/Research-studies/EUGlobal-Public-Goods.pdf> accessed 1 April 2016.

38 Carbone (n 27) 185.

39 Jean Coussy, 'The Adventures of a Concept: Is Neo-Classical Theory Suitable for Defining Global Public Goods?' (2005) 12(1) Rev Intl Pol Econ 177.

40 On the concept of the Washington consensus, see Sarah Babb, 'The Washington Consensus as Transnational Policy Paradigm: Its Origins, Trajectory and Likely Successor’ (2013) 20(2) Rev Intl Pol Econ 268. 
taxes. ${ }^{41}$ This discourse, we contend, has attached an implicit normative undertone to a concept that had initially been designed to describe an objective reality. Therefore, we can now accurately speak of GPGs as a legitimising instrument. In fact, this transformation is splendidly captured by Long and Woolley:

Kaul and her colleagues have increasingly and overtly left the original economic analysis behind, supplementing the idea with concepts and theory from sociology, political science, and other disciplines. But the economic concept is nevertheless still deployed as a signifier or as a persuasive technique, an example of what Donald McCloskey called economic rhetoric. (...) But we should not be deceived: this is a 'UN-plus' framework - the United Nations conceived as a preeminent actor in the world of global public goods, as overseer or coordinator, if not provider. ${ }^{42}$

Not only by adding sociological or political considerations to the concept, but also by depicting GPGs as 'goods and activities with positive utility, including positive externalities', in contrast to global public 'bads' which imply 'public disutility, the UNDP study has moved away from the technical, economic concept. In other words, presenting a policy challenge as a global public 'good' also labels the good in question as something that is normatively positive. For instance, while ozone depletion and global warming would constitute global public 'bads', free vaccinations and reductions of greenhouse gas emissions would represent global public 'goods. ${ }^{44}$ Yet, whereas these simple examples might not raise controversies, people might in fact disagree about the positive or negative externalities of market integration, the prevention of Autoimmune Deficiency Syndrome (AIDS) (in the form of contraception), or nuclear energy. This is why the normative distinction made by the UNDP is entirely absent in economic theory. The word 'good' is normatively neutral in economic theory and, as such, can have both positive and negative connotations. ${ }^{45}$

See, eg, Recommendations of the High-level Panel on Financing for Development (n 31) 9: 'The International Conference on Financing for Development should explore the desirability of securing an adequate international tax source to finance the supply of global public goods.'

42 David Long and Frances Woolley, 'Global Public Goods: Critique of a UN Discourse' (2009) 15(1) Glob Gov 107, 117-18.

43 Kaul, Grunberg and Stern (n 1) 6.

44 Oliver Morrissey, Dirk Willem te Velde and Adrian Hewitt, 'Defining International Public Goods: Conceptual Issues' in Marco A. Ferroni and Ashoka Mody (eds), International Public Goods: Incentives, Measurement and Financing (Kluwer 2002) 35-36.

45 Gregory Shaffer, 'International Law and Global Public Goods in a Legal Pluralist World' (2012) 23 EJIL 669, 673-74. 
The almost ubiquitous references to the 'objective' economic theory of public goods ${ }^{46}$ have come to play the role of a legitimising instrument, not only for the UNDP, but also for some of the international organisations mentioned here. ${ }^{47}$ In this regard, Daniel Bodansky has rightfully argued that, '[r]ecasting an issue in terms of "global public goods" gives it greater status and thus serves a useful rhetorical function. ${ }^{48}$ In the same way as the concept of public goods has served to justify the welfare function of the state at the national level in Samuelson's theory, ${ }^{49}$ the concept of GPGs has been developed 'to enhance the scope for global governance projects and thus legitimize their pursuit. ${ }^{50}$ Therefore, when an international organisation (or other actors for that matter) labels an issue as a GPG, it tacitly presents it as an economic value-free qualification, and thereby attempts to justify its legitimacy to produce or to supervise the production of the good in question.

\subsection{Global public goods as a policy choice}

Akin to the national level, ${ }^{51}$ this economic objectivity can be disputed on the ground that both non-rival and non-excludable aspects are deemed subjective, malleable, or prone to change as technology advances. In fact, most goods cannot be inherently public, they normally become public through public provision. ${ }^{52}$ The choice for (or against) public provision is never a neutral one, as it is generally subject to diverging views. Even goods that are 'de facto public', on account of their non-excludability and non-rivalry, such as the lighthouse, may, under certain circumstances, be considered unworthy of public provision. ${ }^{54}$ For instance, a society could very well decide that, since the lighthouse only benefits foreign ships,

Daniel Bodansky, 'What's in a Concept? Global Public Goods, International Law and Legitimacy' (2012) 23(3) EJIL 651, 655; Coussy (n 39) 178. See text to n 39.

Jean Coussy, 'Biens Publics Mondiaux : Théorie Scientifique, Réalité Émergente et Instrument Rhétorique', in François Constantin (ed), Les Biens Publics Mondiaux: Un Mythe Légitimateur Pour l'Action Collective? (L'Harmattan 2002) 31; Coussy (n 39).

48 Bodansky (n 46) 655.

49 See above text to $n$ 6-9.

50 Shaffer (n 45) 674.

51 See above text to $\mathrm{n}$ 6-9.

52 See, eg, Marmolo (n 10) 28; John Hudson, Philip Jones, “Public Goods”: An Exercise in Calibration' (2005) 124 Public Choice 267, 268; Séverine Deneulin, Nicholas Townsend, 'Public Goods, Global Public Goods and the Common Good' (2007) 34 Intl J Soc Econ 19, 23.

53 Inge Kaul, 'Global Public Goods: Explaining their Underprovision' (2012) 15(3) JIEL 729, 731.

54 See, eg, Deneulin, Townsend (n 52) 23. 
it will not bear the cost thereof. The authors of the UNDP study acknowledge this very basic fact as well: "[p]ublic" and "private" are in many-perhaps most-cases a matter of policy choice: a social construct. ${ }^{55}$

GPGs should thus be redefined, not as goods that are purely non-rival and nonexcludable at the global level, but as 'goods that are in the global public domain. ${ }^{56}$ It is not because the WB labels 'free and open trade' as a $\mathrm{GPG}^{57}$ that trade integration is good per se-presenting free trade as a global regulatory goal is a policy choice, which should be subject to a democratic debate. Even less controversial examples of GPGs, such as climate change mitigation ${ }^{58}$ raise questions as to why to prioritise this particular good (eg over free trade and market efficiency), how to produce the good in question (eg through windmills or nuclear plants), and who should pay (eg developed or developing countries). Undeniably, this requires a number of policy choices to be made. ${ }^{59}$ While we may all agree on certain generally defined GPGs, such as human rights protection or the eradication of infectious diseases, the devil lies in the details. As the International Task Force on GPGs has acknowledged, '[a] critical reality of global public goods is that they are contested; states have different interests, values and preferences, even where they share long-term goals. ${ }^{60}$ Indeed, there is no such thing as a 'natural' GPG, neutrally deducted from objective categories; defining or determining GPGs is always a matter of policy choice.

\subsection{Global public goods as the ideal outcome of a democratic decision- making process}

Once we realise that defining GPGs involves the making of essential policy choices, the underlying issue of a legitimate and democratic decision-making process becomes all the more important. We have already noted here that, at the national level, the State is, most often, in a position to gauge the diverging interests, values and preferences of its citizens through majoritarian, democratic, and constitutional 
checks and balances. ${ }^{61}$ At the global level, however, the current horizontal, decentralised, and fragmented legal order arguably obstructs the construction of a similar democratic process.

The first UNDP study emphasised from the very beginning that, akin to the national level, 'most judgments of what is desirable [at the global level] can only be the result of a political process', and that this process 'has to be made transparent and participatory. ${ }^{62}$ In this sense, Kaul et al. argue that other important actors, such as NGOs, civil society, and the private sector should be included in decisionmaking processes at the global level. Interestingly, the Task Force on GPGs has also echoed this concern by characterising GPGs as issues 'that are defined through a broad international consensus or a legitimate process of decision-making. ${ }^{63}$

While this should, indeed, be the case, Kaul et al. have nonetheless pinpointed the existence of a 'participation gap' as one of the three central limitations of the current global governance architecture. ${ }^{64}$ The participation gap essentially refers to the under-representation of many relevant stakeholders, in particular the marginal and voiceless groups. ${ }^{65}$ This gap results largely from the fact that international cooperation remains primarily intergovernmental, although we now live in a multi-actor world. Appropriately, then, Kaul and Mendoza have called 'for the matching of the circle of stakeholders in a particular public good with the circle of participants in negotiations on its provision, either with a consultative or a decisionmaking voice. ${ }^{66}$ The EU Commission too has indicated that it views this so-called 'participation gap' as one of the major shortfalls of the current policy-making arrangements at the global level. In the Commission's opinion, any decisions on GPGs are political choices in which the maximum involvement of all those affected is crucial. ${ }^{67}$ It seems, therefore, that enhanced participation in the decision-making process on GPGs has become a basic precondition for a more legitimate policy-making architecture.

Of course, this begs the question who exactly should be given enhanced participation rights. Unfortunately, the scope of this article does not allow for a thorough discussion of this question. However, we would like to indicate that

61 See above text to n 6-9.

62 Kaul, Grunberg and Stern (n 1) 6.

63 International Task Force on Global Public Goods (n 30) x.

64 See Kaul, Grunberg and Stern (n 1) xxvi. See also above text to n 23.

65 ibid.

66 Kaul and Mendoza (n 55) 91.

67 See European Commission (n 37). 
any attempt at an answer should be two-phased. First, the 'marginal and voiceless' groups, or 'disregarded' as Stewart calls them, ${ }^{68}$ should be identified. In other words, this would normally require an analysis of which groups are currently not heard in the global public debate, which may differ from one governance structure to another. Secondly, it should be determined how and by whom these groups would best be represented. This can, for example, require an enhanced role for certain developing States to counter the hegemonic tendencies of international law. In other cases, and we would argue that these cases arise quite often, a more prominent role for NGOs might be (part of) the solution.

\section{Global public goods in international legal scholarship}

\subsection{A burgeoning legal scholarship with a focus on output legitimacy}

Surprisingly, the concept of GPGs has attracted very little attention from international legal scholars, with the majority of authors writing on the topic coming from fields such as economics, political sciences, or international relations. International law has been relatively late in taking notice of the GPGs debate, since it took some years after the publication of the three UNDP volumes on GPGs before a limited, but slowly increasing number of legal scholars have started joining the debate. ${ }^{69}$

Richard B Stewart, 'Remedying Disregard in Global Regulatory Governance: Accountability, Participation, and Responsiveness' (2014) 108(2) AJIL 211.

69 Actually, the majority of legal articles that tackle the GPGs question can be traced back to four fairly recent symposia: (i) the symposium edition of the Journal of International and Economic Law, which published four of the papers presented at the European University Institute's (EUI) February 2011 conference on Multilevel Governance of Interdependent Public Goods. See Ernst-Ulrich Petersmann, 'Mini-Symposium on Multilevel Governance of Interdependent Public Goods. Introduction and Overview: A Research Agenda for Making Global Public Goods Theory More Policy Relevant' (2012) 15(3) JIEL 709; Pascal Lamy, 'Global Governance: From Theory to Practice' (2012) 15(3) JIEL 721; Kaul (n 53) 729; Jan Wouters and Thomas Ramopoulos, 'The G20 and Global Economic Governance: Lessons from Multi-Level European Governance?' (2012) 15(3) JIEL 751; Daniel C Esty and Anthony L I Moffa, 'Why Climate Change Collective Action has Failed and What Needs to be Done Within and Without the Trade Regime' (2012) 15(3) JIEL 777; (ii) the 2012 volume of the Duke Journal of Comparative \& International Economic Law, where two of the papers presented at a roundtable organised between distinguished American scholars at Duke Law on 22 October 2011 were published: David Gartner, 'Global Public Goods and Global Health' (2012) 22 Duke J Comp \& Intl L 303; 
While some of these scholars use the GPGs concept as a new spectrum to rehash existing issues of international law, ${ }^{70}$ others identify the provision of GPGs as a brand-new challenge for international law, ${ }^{71}$ and most, if not all, conclude that international law could, in fact, contribute to the effective provision of GPGs. ${ }^{72}$ For instance, Bodansky justly argues that, '[s]ince global public goods cannot be adequately produced by the market, we need international institutions and international law to provide them. ${ }^{73}$ Likewise, Trachtman contends that international law 'comprise[s] a kind of rudimentary government' to provide GPGs, ${ }^{74}$ whereas Shaffer affirms that international law is required to produce global public goods. ${ }^{75}$

However, the vast majority of legal scholars writing on the topic argue that international law as it currently stands, with its cardinal principles of state sovereignty and state consent, constitutes a hindrance to the effective provision of

Timothy Meyer, 'Global Public Goods, Governance Risk, and International Energy' (2012) 22 Duke J Comp \& Intl L 319; (iii) the 2012 volume of the European Journal of International Law, which published eight articles presented at the European Society of International Law and American Society of International law joint symposium organised at EUI on Global Public Goods and the Plurality of Legal Orders: Fabrizio Cafaggi and David D Caron, 'Global Public Goods amidst a Plurality of Legal Orders: A Symposium’ (2012) 23(3) EJIL 643; Bodansky (n 46); Shaffer (n 45); Fabrizio Cafaggi, 'Transnational Private Regulation and the Production of Global Public Goods and Private "Bads"' (2012) 23(3) EJIL 695; Francesco Francioni, 'Public and Private in the International Protection of Global Cultural Goods' (2012) 23(3) EJIL 719; Petros C Mavroidis, 'Free Lunches? WTO as Public Good, and the WTO's View of Public Goods' (2012) 23(3) EJIL 731; Elisa Morgera, 'Bilateralism at the Service of Community Interests? Non-Judicial Enforcement of Global Public Goods in the Context of Global Environmental Law' (2012) 23(3) EJIL 74; André Nollkaemper, 'International Adjudication of Global Public Goods: The Intersection of Substance and Procedure' (2012) 23(3) EJIL 769. See also Issue 1 of Volume 23 of the Indiana Journal of Global Legal Studies, which published two articles on GPGs presented at a colloquium hosted by the Stellenbosch Institute for Advanced Study on Global Human Rights Law and the Boundaries of Statehood: Daniel Augenstein, 'To Whom it May Concern: International Human Rights Law and Global Public Goods' (2016) 23(1) Ind J Global Legal Stud [forthcoming]; Neil Walker, 'Human Rights and Public Goods: The Sound of One Hand Clapping?' (2016) 23(1) Ind J Global Legal Stud [forthcoming].

70 See, eg, Gartner (n 69), reviewing the role of international law in the prevention or containment of communicable diseases; Morgera (n 69) where the author tackles the issue of non-judicial enforcement of global public goods in the context of global environmental law. See, eg, Bodansky (n 46).

72 See Shaffer (n 45).

73 Bodansky (n 46) 652.

74 Joel P Trachtman, The Future of International Law: Global Government (CUP 2013) 9.

75 Shaffer (n 45) 670-71. 
GPGs. Shaffer, for example, warns that international law could 'potentially impede [the] dynamic processes that are needed to address global public goods challenges. ${ }^{, 76}$ Moreover, Nico Krisch asserts that 'classical international law' is inadequate in providing proper solutions to the challenges posed by the provision of GPGs. ${ }^{77}$ Similarly, Trachtman argues that, '[i]n the international system, based as it is on individual state consent, it may be tougher to make rules that would bind free riders. $^{78}$ In this sense, Petersmann, too, concludes that, to limit the participation problem, one would need 'rights-based rules, institutions and governance mechanisms that go beyond those of "Westphalian intergovernmentalism"."79 In other words, most legal scholars argue that international law de lege lata, ie organised along Westphalian lines, is ill-suited to the provision of GPGs as it lacks coercive mechanisms, but equally contend that international legal rules and institutions are essential to establishing exactly those coercive mechanisms that are currently lacking. In order adequately to provide GPGs, a major overhaul of the international legal system would thus be required.

This fairly radical critique of the current international legal system actually finds its origin in older publications on GPGs. The International Task Force on GPGs opened its final report by highlighting this exact issue, namely that the principles of state sovereignty and state consent are a major obstacle for the effective provision of GPGs and the "basic problem [that] underlies all others. ${ }^{\text {, }}$ In the same vein, the economist William Nordhaus emphasises that, 'under international law (...), there is no legal mechanism by which disinterested majorities, or supermajorities short of unanimities, can coerce reluctant free-riding countries into mechanisms that provide for global public goods. ${ }^{81}$ In his view, international law should 'come to

76 ibid 671.

77 Nico Krisch, 'The Decay of Consent: International Law in an Age of Global Public Goods' (2014) 108(1) AJIL 1.

78 Trachtman (n 74) 154.

79 Ernst-Ulrich Petersmann, 'Introduction and Overview: Lack of Adequate Theories, Rules and Institutions for the Central Policy Challenge in the 21st Century?' in Ernst-Ulrich Petersmann (ed), Multilevel Governance of Interdependent Public Goods Theories, Rules and Institutions for the Central Policy Challenge in the 21st Century, EUI Working Paper RSCAS 2012/23, 46 $<$ http://cadmus.eui.eu/bitstream/handle/1814/22275/RSCAS_2012_23final.pdf?sequence =2> accessed 1 April 2016.

80 International Task Force on Global Public Goods (n 30) xi.

81 William D Nordhaus, 'Paul Samuelson and Global Public Goods' (5 May 2005) $7<$ http://www. econ.yale.edu/ nordhaus/homepage/PASandGPG.pdf > accessed 1 April 2016. 
grips with the fact that national sovereignty cannot deal with critical global public goods.

The fact that the classical view on international law is increasingly rejected by the GPG literature is no surprise. The prisoner's dilemma, on which the GPGs theory is based, ${ }^{83}$ outlines a situation whereby two prisoners are unable to communicate and therefore act solely in their own rational self-interest. As a result, both prisoners confess and each serves more years in prison than they would have if they had established a common strategy. Much like the individuals in the prisoner's dilemma, it is expected that sovereign States acting in total independence will defect from cooperation unless coercive mechanisms are introduced. ${ }^{84}$ What this analogy highlights is that, in order to coerce free-rider States, we need to transpose certain domestic strategies at the global level. ${ }^{85}$ For instance, the Report of the High-level Panel on Financing for Development has proposed that the supply of GPGs be financed through global taxation. ${ }^{86}$ For some legal scholars, it seems, the solution to this inextricable dilemma is to impose inter-state cooperation by 'design[ing] punishments that are sufficient to induce compliance. ${ }^{, 87}$ Nico Krisch equally argues that the effective supply of GPGs calls for a 'turn to non-consensual law making mechanisms, especially through powerful international institutions with majoritarian voting rules. ${ }^{88}$ In the models promoted by these authors, decisions on GPGs appear to be legitimised through the effectiveness of the output.

\subsection{Democracy: The missing link}

This emerging scholarship is, of course, welcome. However, as we have previously noted, the focus mainly lies on the effective supply of GPGs, whereas the process of defining and identifying which 'goods' to provide collectively at the global level seems to constitute a blind spot in the current international legal discourse. We

ibid 8.

See Kaul, Grunberg and Stern (n 1) 7. ibid 8.

François Constantin, 'Les Biens Publics Mondiaux, Un Imaginaire Pour Quelle Mondialisation?' in Constantin (n 44) 81.

See above text to $\mathrm{n}$ 39. See also Recommendations of the High-level Panel on Financing for Development (n 41) 9.

Trachtman (n 74) 161.

Krisch (n 77) 1. 
find that the link between GPGs, international law, and democracy remains highly unexplored and that very few scholars actually discuss the role that international law could play in guaranteeing a democratic decision-making process on GPGs. This is highly unfortunate, particularly since the UNDP study on GPGs highlights the democratic deficit inherent in the mechanisms that provide public goods at the global level-most notably, the so-called 'participation gap. ${ }^{, 89}$ Therefore, if international legal scholarship is to help design appropriate decision-making processes on GPGs, matters of democratic legitimacy and participation should be kept at the forefront of this debate.

It is an interesting, yet largely unexplored question in the literature on GPGs, whether democratic ideals would be better served by a reconfiguration of the international legal order towards centralised and non-consensual coercive mechanisms, rather than traditional multilateral law-making mechanisms established on State sovereignty and State consent. In our opinion, rather than closing the current 'participation gap' in global governance, the erosion of the consensual underpinnings of international law runs the risk of widening it. ${ }^{90}$ Although we plea in this paper for enhanced participation of different (nonState) actors, we readily admit that States remain central to the representation of individuals' interests and concerns at the global level, through the democratic procedures established at the State level. Consequently, majoritarian (or otherwise non-consensual) decision-making at the global level might lead to further disregard for the interests of States belonging to the minority or the non-consenting. In this regard, Krisch himself admits that anti-consensual arguments, inspired by an urgency to solve collective-action problems, might, in fact, raise deeper concerns from a democratic perspective. ${ }^{91}$ Therefore, what we discuss here can be best understood as an addition to, rather than as a 'bouleversement', of the existing international legal order.

At this point, we wish to distance ourselves from issues regarding the provision of GPGs by raising a preliminary question which we contend merits as much, if not more, attention from legal scholarship: whether (and how) the decision-making

90 Helen Keller, 'Codes of Conduct and Their Implementation: The Question of Legitimacy' in Rüdiger Wolfrum and Volker Röben (eds), Legitimacy in International Law (Springer 2008) 257. 
processes underlying the definition of GPGs can be democratised. Even Krisch, who points to the 'shift from input to output legitimacy,' ${ }^{92}$ admits that:

The actual provision of public (...) goods will hardly ever serve entirely to remove questions of input legitimacy from view: even if everybody receives benefits from an institution, some typically gain more and some less; distributional conflict remains ubiquitous. ${ }^{93}$

In our view, the logic of efficiency or urgency cannot sufficiently legitimise the emergence of centralised and non-consensual coercive mechanisms at the global level. Rather than simply dismissing consensualism in the name of effective provision, we argue that an alternative set of 'global democratic checks' is much needed. ${ }^{94}$ In this regard, it is our belief that international legal scholarship can contribute to rendering decisions on GPGs more adjusted to the preferences of world citizens, or, in other words, impose a constraint on the unilateral definition of global public goods. ${ }^{95}$

\section{The way forward: Bridging the participation gap}

\subsection{The participation gap in international legal scholarship}

Within a liberal democratic State, legally defined procedures serve to ensure that decision-making processes on public goods are democratic. Conversely, within the horizontal and decentralised international legal order, a similar process on GPGs does not exist. Indeed, as Shaffer explains, contrary to the national level, where citizens are normally involved in decision-making processes on public goods, ${ }^{96}$ at the global level, ' $[w]$ e face considerable obstacles in (...) revealing preferences through democratically accountable international institutions. ${ }^{97}$ In this respect, while we remain thoroughly aware that a more developed account of the principles likely to democratise the policy choices on GPGs is warranted, we have chosen

92 ibid 6.

93 Krisch (n 12) 250.

94 Shaffer (n 45) 693.

95 Nico Krisch, 'International Law in Times of Hegemony: Unequal Power and the Shaping of the International Legal Order' (2005) 16(3) EJIL 369, 395.

96 See above text to $n$ 6-9.

97 Shaffer (n 45) 693. 
to operate on a narrower normative basis here. More precisely, our focus will lie mainly with the 'participation gap' identified by the UNDP study as part of the larger democratisation process underlying the definition of GPGs. Arguably, in this manner we can contribute more effectively to a debate that is, to say the least, extremely broad.

We note, however, that the issue of public participation (or lack thereof) in the decision-making processes at the global level is not entirely unexplored by legal scholars. In fact, the democratic deficit in international law has been the concern of a growing number of legal authors. For instance, Gráinne de Búrca has called for a 'democratic-striving or democracy-developing approach', whereby, rather than effectiveness or efficiency (in the provision of GPGs, for example), principles relating to the participation and representation of relevant stakeholders would be paramount to the global governance structure. ${ }^{98}$ Still, applying democratic theories developed for the nation-state to the global level has proven, at best, impractical. This, Bodansky argues, has prompted a re-orientation of scholarship toward 'particular aspect[s] of democracy, namely public participation.' Indeed, since the provision of public goods is no longer the exclusive responsibility of States, but one that is shared with the UN and other global actors, 'rights of political participation' should not be limited to the domestic level. ${ }^{100}$

In particular, two emerging fields of international law are of interest here: global administrative law and global constitutionalism, as these attempt to bridge the participation gap in global governance (and, implicitly, the governance of GPGs) by extending domestic administrative and constitutional tools to the global level. Of course, the challenges of transposing participation as a democratic standard from the State to the global level are enormous. The founders of global administrative law readily admit that the pragmatic steps toward greater inclusiveness 'fall short of representation of the public on a basis equivalent to domestic electoral mechanisms and thus will not be able to justify the exercise of administrative authority on a 101.

99 Daniel Bodansky, 'The Legitimacy of International Governance: A Coming Challenge for International Environmental Law?' (1999) 93(3) AJIL 596, 617.

100 Steven Wheatley, The Democratic Legitimacy of International Law (Hart 2010) 329; this argument is built on observations previously made by Bhikhu Parekh. See Bhikhu Parekh, 'Cosmopolitanism and Global Citizenship' (2003) 29(1) Rev of Intl Studies 3. 
fully democratic basis. ${ }^{101}$ The same is true of global constitutionalism. As Neil Walker indicates, 'there is no world demos and no democratically supported world constitutional regime available to authorize the terms and conditions of supply of the various [global public] goods, still less (...) to decide the balance between them. ${ }^{102}$ Taking these basic caveats into account, the question then becomes: how could global administrative law and global constitutionalism contribute to redressing the participation gap in the decision-making processes on GPGs?

\subsection{Global administrative law}

A first analytical and normative framework that promotes participation as one of the legitimising standards in global regulatory processes, such as trade, investment, security enforcement, health, education, or environmental protection, is the global administrative law project developed at New York University. In the protagonists' own words, this relatively new field of international law is essentially preoccupied with:

the mechanisms, principles, practices, and supporting social understandings that promote or otherwise affect the accountability of global administrative bodies, in particular by ensuring [that] they meet adequate standards of transparency, participation, reasoned decision, and legality, and by providing effective review of the rules and decisions they make. ${ }^{103}$

Global administrative law essentially focuses on treaty-based intergovernmental regulatory bodies (such as those cited above, i.e. UNIDO, the FAO, the WB, the OECD, and the WHO), but also on public-private partnerships (such as the Codex Alimentarius Commission), or even private bodies (such as the International Standardization Organisation (ISO)). What is at stake here is how 'to address the problem of disregard' by 'reforming and using the institutional mechanisms and arrangements that currently exist or that could be developed' in these transnational administrative bodies which are generally not subject to the legal or political control that is normally present in domestic settings. ${ }^{104}$

101 Benedict Kingsbury, Nico Krisch and Richard B Stewart, 'The Emergence of Global Administrative Law' (2004-2005) 68 L Contemp Probs 15, 50.

102 Neil Walker, Intimations of Global Law (CUP 2014) 123.

103 Kingsbury, Krisch and Stewart (n 101) 17.

104 Stewart (n 68) 213. 
While not expressly stated as such in the literature, the global administrative law approach seems to apply the same kind of reasoning to global regulatory bodies as that of the GPGs project. That is, in the same way as States have gradually developed complex administrative legal mechanisms to control agencies responsible for the provision of public goods at the national level, the global administrative law approach could address the participation gap at the level of increasingly powerful global regulatory bodies charged with the definition of GPGs. Not only this, but global administrative law also recognises that States are no longer the sole subjects of global administration. This approach breaks down the 'domestic-international dichotomy': like States, individuals, corporations and NGOs might be affected by decisions of global regulatory mechanisms and therefore must also be heard and allowed to participate in the decision-making processes of global regulatory regimes. ${ }^{105}$ Accordingly, it is not sufficient any more to argue that global regulatory bodies are in principle accountable to national governments. Global administrative law invites legal scholars to look for alternative and more demanding checks and balances to constrain the definition of GPGs in specialised and decentralised global regulatory bodies.

Without going into overly theoretical debates, global administrative legal scholars attempt to boost the legitimacy of the global governance system by extending domestic law and implementing new participatory mechanisms to specific and fragmented global regulatory regimes. ${ }^{106}$ In this regard, practical mechanisms that address the 'participation gap' have already emerged in specific and compartmentalised regimes of international law. ${ }^{107}$ There are many examples in this sense. For instance, in the field of economic development law, when the WB decided to review its Environmental and Social Safeguard Policies in 2012, it invited a wide range of stakeholders-representatives of government, international organisations, civil society, academia, and the private sector-to participate in the consultation meetings on the proposed reform. ${ }^{108}$ In the field of international

105 See Kingsbury, Krisch and Stewart (n 101) 23-25.

106 Krisch (n 12) 257.

107 For an overview, see Sabino Cassese, 'A Global Due Process of Law?' in Gordon Anthony, JeanBernard Auby, John Morison and Tom Zwart (eds), Values in Global Administrative Law (Hart 2011).

108 All information related to the consultation and review process of the WB's Environmental and Social Framework is available online: World Bank, 'Review and Update of the World Bank Safeguard Policies' (2015) <http://consultations.worldbank.org/consultation/review-andupdate-world-bank-safeguard-policies> accessed 1 April 2016. 
environmental law, the Aarhus Convention on Access to Information, Public Participation in Decision-making and Access to Justice in Environmental Matters stipulates that:

Each Party shall promote the application of the principles of this Convention [including the principle of public participation] in international environmental decision-making processes and within the framework of international organizations in matters relating to the environment. ${ }^{109}$

In the field of international food law, it is also noticeable that, apart from 186 member States, 234 observing international organisations, NGOs and UN agencies are included in the Codex Alimentarius Commission which outlines nonbinding international food standards and codes of practice. ${ }^{110}$ The aim of global administrative law, it appears, is to further discern and extend the application of such participatory tools to constrain the definition of GPGs in global regulatory bodies.

However, pragmatism might represent the main limitation of global administrative law. ${ }^{11}$ It is true that democratic legitimacy is generally put forward as one of the three possible normative conceptions underlying the global administrative law research project. ${ }^{112}$ Yet, accountability, it appears, is the key word for global administrative law, and democracy seems to play a secondary role only. ${ }^{113}$ Participation mechanisms constitute just one part of the global administrative law paraphernalia that could enhance the accountability of global regulatory bodies, next to transparency, the requirement for reasoned administrative decisions, judicial review, and substantive standards for sound administrative action. ${ }^{114}$ In this respect, Krisch, one of the co-founders of the global administrative law project, indicates that the school's 'more limited ambition creates serious problems, not least because questions of overall structure can hardly be disentangled-practically and normatively-from those of concrete accountability mechanisms. ${ }^{115}$ While Shaffer,

109 Convention on Access to Information, Public Participation in Decision-Making and Access to Justice in Environmental Matters (adopted 25 June 1998, entered into force 30 October 2001), 2161 UNTS 447, Article 3(7).

110 Codex Alimentarius, 'Codex Members and Observers' <http://www.codexalimentarius.org/ members-observers/en/> accessed 1 April 2016.

111 See Krisch (n 12).

112 Kingsbury, Krisch and Stewart (n 101) 48-51.

113 Krisch (n 12) 256.

114 See Kingsbury, Krisch and Stewart (n 101) 37-42.

115 Krisch (n 12) 265. 
too, notes that 'the global administrative law approach is rather technocratic and thus lacks ambition regarding larger scale questions of governance requiring political decision-making for the production of global public goods. ${ }^{116}$ In fact, decisions on GPGs are sometimes more easily characterised as constitutional, legislative, or even judicial activities, rather than administrative ones. ${ }^{117}$ Contemplate, for instance, the dilemma within the EU as to whether human rights should trump fundamental market freedoms. ${ }^{118}$ In our view, issues of such political salience cannot be left in the hands of specialised and fragmented global administrative bodies, but must be adjudicated on the basis of more overarching constitutional principles.

\subsection{Global constitutionalism}

Another set of interesting responses to the limitations which have just been observed in global administrative law could potentially be found in global constitutionalism. ${ }^{119}$ This school of thought offers an analytical framework that attempts (empirically) to describe the foundations of global governance, and (normatively) to tackle the challenges posed by this 'new world order. ${ }^{120}$ While there is arguably no document that could currently serve as 'a global constitution, ${ }^{121}$ global constitutionalists argue that the extension of constitutional principles and more centralised decision-making mechanisms at the global level would improve the democratic underpinnings of the international legal order.

A number of legal scholars writing on GPGs view global constitutionalism as the most suitable framework for reconfiguring the world legal order. Auby, for instance, suggests that the global administrative law approach should be supplemented by a constitutionalisation of international bodies, which, he contends,

116 See Shaffer (n 45) 689.

117 See Jean-Bernard Auby, 'Public Goods and Global Administrative Law' in Gordon Anthony, Jean-Bernard Auby, John Morison and Tom Zwart (eds), Values in Global Administrative Law (Hart 2011) 248.

118 See, eg, Case C-112/00 Eugen Schmidberger, Internationale Transporte und Planzüge v Republik Österreich [2003] ECR I-5659.

119 See Anne Peters, 'The Merits of Global Constitutionalism' (2009) 16(2) Ind J Global Legal Stud 397-411.

120 On what this new order entails, see Anne-Marie Slaughter, A New World Order (PUP 2005).

121 Contra Bardo Fassbender, 'The United Nations Charter as Constitution of the International Community' (1998) 36(3) Colum J Transnat'l L 529. 
'is the only way by which the public goods of which global bodies are in charge with (...) would clearly be determined on the face of the record. ${ }^{122}$ The 'identification' of GPGs, he claims, must be built on a 'democratic and constitutional' foundation. ${ }^{123}$ This is also the main message conveyed in Petersmann's last book:

As multilevel governance of interdependent international public goods has become the most challenging policy task in the twenty-first century-the current undersupply of international public goods requires embedding [international economic law] into stronger constitutional, cosmopolitan and democratically justifiable foundations. ${ }^{124}$

Augenstein similarly notices the strong appeal of global constitutionalism in response to the 'cross-functional' and 'cross-territorial' impacts of GPGs on international law-that is, respectively, the fragmentation and the lack of procedural and substantive legitimacy of international law. ${ }^{125} \mathrm{Kumm}$, in turn, observes that international constitutionalists 'point to interdependencies and make functional arguments about the need to provide GPGs that states cannot provide by themselves. ${ }^{126}$ However, Shaffer indicates that there is still much ground to cover and, as such, encourages global constitutionalists to engage more deeply with the issue of GPGs, in particular by designing 'democratic checks and balances at the international level. ${ }^{127}$

The authors mentioned here focus on different aspects of global constitutionalism. Among the prevailing visions on global constitutionalism, ${ }^{128}$ the international community school-whose protagonists include Simma ${ }^{129}$ and

123 ibid.

124 Ernst-Ulrich Petersmann, International Economic Law in the $21^{\text {st }}$ Century: Constitutional Pluralism and Multi-level Governance of Interdependent Public Goods (Hart 2012) 25; see also Ernst-Ulrich Petersmann, 'De-Fragmention of International Economic Law Through Constitutional Interpretation and Adjudication with Due Respect for Reasonable Disagreement' (2008) 6 Loyola U Chicago Intl L Rev 209, 217.

125 Augenstein (n 69) 16.

126 Mattias Kumm, 'The Cosmopolitan Turn in Constitutionalism: An Integrated Conception of Public Law' (2013) 20(2) Ind J Global Legal Studies 605, 611.

127 Shaffer (n 45) 686.

128 For an overview of the different visions on global constitutionalism, see Christine E J Schwöbel, 'Situating the Debate on Global Constitutionalism' (2010) 8(3) Int'l J Constitutional L 611.

129 See, eg, Bruno Simma, 'From Bilateralism to Community Interest in International Law' (1994) 250 Recueil de Cours 217; Bruno Simma and Andreas L Paulus, 'The "International Community": Facing the Challenge of Globalization' (1998) 9(2) EJIL 266. 
Tomuschat ${ }^{130}$ - seems the most noteworthy with respect to the debate on GPGs and democracy. ${ }^{131}$ This vision of an international community offers, we believe, at least two valuable analytical and normative insights on how international law could become more conducive to filling the participation gap in the definition of GPGs.

First, the idea of an international community goes beyond the voluntarist tradition of international law by postulating that 'humanity, not sovereignty ${ }^{132}$ is the ultimate source of international law. In this respect, Villalpando signals a paradigm shift in international law from egoistic state interests to community interests in the form of what he interestingly refers to as 'public goods. ${ }^{133}$ The emergence of jus cogens norms (articles 53 and 64 of the Vienna Convention on the Law of Treaties ${ }^{134}$ ), erga omnes obligations, ${ }^{135}$ and the prevalence of the obligations of UN Member States over their obligations under any other international agreement (article 103 of the UN Charter ${ }^{136}$ ) are all manifestations in positive international law of the concern for the protection of community interests, and implicitly, GPGs. Such principles of international law undoubtedly contribute to the vertical integration of the international legal order by recognising public goods which transcend state interests as global challenges.

The second major attribute of the international community approach, at least with respect to the concerns that have been unravelled in the present article, is that it aims to enlarge the global community by including actors other than States. ${ }^{137}$

130 See, eg, Christian Tomuschat, 'International Law: Ensuring the Survival of Mankind on the Eve of a New Century' (1999) 281 Recueil de Cours 237; Christian Tomuschat, 'Obligations Arising for States Without or Against Their Will' (1993) 241 Recueil de Cours 195.

131 For the first apparition of the term of 'Doctrine of International Community', see Fassbender (n 121) 546; see also Bardo Fassbender, 'The Meaning of International Constitutional Law' in Ronald St John MacDonald and Douglas M Johnston (eds), Towards World Constitutionalism (Martinus Nijhoff 2005) 838.

132 Anne Peters, 'Membership in the Global Constitutional Community' in Jan Klabbers, Anne Peters and Geir Ulfstein (eds), The Constitutionalization of International Law (OUP 2009) 155.

133 Santiago Villalpando, 'The Legal Dimension of the International Community: How Community Interests Are Protected in International Law' (2010) 21(2) EJIL 387, 392.

134 Vienna Convention on the Law of Treaties (adopted 23 May 1969, entered into force 27 January 1980) 1155 UNTS 331.

135 See Case Concerning the Barcelona Traction, Light and Power Company, Limited (Belgium v. Spain) (Merits) [1970] ICJ Rep 3, [33]-[34].

136 Charter of the United Nations (adopted 26 June 1945, entered into force 24 October 1945) 892 UNTS 119.

137 Peters (n 132) 153; see also Anne Peters, 'Humanity as the A and $\Omega$ of Sovereignty' (2009) 20(3) EJIL 513. 
To be legitimate, the said GPGs need to account for the preferences of world citizens. Indeed, the international community school looks at the participation of international organisations, NGOs, individuals, transnational corporations, or even hybrid actors as a means of both limiting and justifying power in the definition of GPGs. This strand of global constitutionalism asserts that all affected stakeholders should acquire at least some sort of limited law-making powers at the global level. In a nutshell, participation should be expanded, structured, and formalised. In this regard, the vision advanced by the international community school could function as a heuristic device or a guideline for the interpretation of international law towards a community that is more constitutionalised and, therefore, more involved in the definition of GPGs.

\section{Conclusion}

This contribution started from the idea that the definition of GPGs goes beyond neutral, economic considerations, but inevitably entails policy choices. Mainly, our purpose was to indicate how international legal scholarship could aid in redressing one of the most prevalent flaws of the current global governance system: the 'participation gap' highlighted by the UNDP study. Yet, our concern was not so much with how the discipline of international law could facilitate the economically effective production and supply of GPGs, but the role that it might play in the preliminary stage of democratically defining GPGs-a process that is too often ignored in the policy discourse of international organisations and even in international legal literature. Urgency to solve collective-action problems at the global level has prompted some scholars to plead against the centuries-old principles of state sovereignty and state consent by relying on the GPGs discourse in economic theory. However, dismissing the Westphalian tradition as outdated, could, in the end, trigger an even greater democratic dilemma.

For this reason, we sought answers with two modern approaches to international law: global administrative law and global constitutionalism. Both intellectual frameworks, we found, could serve to render the process of defining the global public domain more accountable to the preferences of world citizens. They could do so by extending domestic and implementing new participatory mechanisms to the global regulatory sphere (global administrative law) and by including actors other than States in the formal structure of law-making at the international level (global constitutionalism). Notwithstanding the absence of a world government, both visions of international law remain valuable to structure 
and further inspire the debate on how to democratically define GPGs beyond the traditional requirement of State consent. Indeed, neither school of thought satisfies itself that citizens' preferences are represented through the basic requirement of State consent in public international law. Neither of the two fields, it seems, views democratic guarantees of public participation as exclusive to the national level anymore. This, we believe, is what makes both projects so relevant for the question posed here.

However, our findings come with an important caveat: the normative and practical power of international law does not, in the end, depend on the use of terms such as 'global administrative law' or 'global constitutionalism', but rather, on concrete institutions, principles, and rules. ${ }^{138}$ In this regard, much remains to be done to connect these two visions with the decision-making process underlying the definition of GPGs. These issues lay the groundwork for our research agenda at the Leuven Centre for Global Governance Studies' Programme on 'Global Governance and Democratic Government. ${ }^{139}$

138 Peters (n 132) 157.

139 See Leuven Centre for Global Governance Studies, 'Research Programme Global Governance and Democratic Government' (2008) <https://ghum.kuleuven.be/ggs/projects/research_ programme> accessed 1 April 2016. 